\title{
Virtuous and Purposeful Leadership
}

\section{It is not enough that the trains are on time}

\begin{abstract}
Where the mind is without fear and the head held high;
Where knowledge is free;

Where the world has not been broken up into fragments by narrow domestic walls; Where words come out from the depth of truth;

Where tireless striving stretches its arms towards perfection;

Where the clear stream of reason has not lost its way into the dreary desert sand of dead habit;

Where the mind is led forward by Thee into ever-widening thought and action; Into that heaven of freedom, my Father, let my country awake.
\end{abstract}

Rabindranath Tagore, 2011, pp. 27-28

Our greatest challenges also need global responses - like ending terrorism, fighting climate change, and preventing pandemics. Progress now requires humanity coming together not just as cities or nations, but also as a global community. I am reminded of President Lincoln's remarks during the American Civil War: "We can succeed only by concert. It is not 'can any of us imagine better?' but, 'can we all do better?"

Mark Zuckerberg, $2017^{2}$

\footnotetext{
${ }^{1}$ Tagore, R. (2011). Gitanjali (Dover Thrift editions). Mineola, NY: Dover Publications.

${ }^{2}$ Ingram, M. (2017). Here's the full text of Mark Zuckerberg's manifesto. Retrieved from http://fortune.com/2017/02/17/mark-zuckerberg-manifesto-text/.
} 


\section{Character and Strength: Leadership as a Virtuous Pursuit}

A gale-force wind of arrant self-interest and righteous indifference is blowing through the world. The angels of humanity's better nature are in hapless disarray - unable, and at times unwilling to weather the storm. In a "post-truth world," ${ }^{3}$ objective fact is irrelevant, disconfirming data is "fake news," pro-sociality and reciprocity are a weak survival strategy, and nations seek greatness by pitting their own peoples against each other and vilifying "outsiders" in zero-sum games.

Internationally, regionally, nationally and locally, moral compasses are being rudely recalibrated to new and alarmingly inhumane "true norths." It appears that the very notion of a universally understood and empathic definition of human advancement has become anathema. Alarmingly, it has taken mere months and a handful of leaders to make the world collectively regress back to a moral low-ground that it had taken many centuries to leave behind. We may have gotten the leaders we deserve, but sadly, they have now forced us to live in a world we do not desire.

Paradoxically, this singularly bleak backdrop, has an elevating call to a purposeful life at its core. Businesses cannot succeed in communities that fail. As a business leader, your conscience must ask you questions that pierce expediency and vanity, and call on your courage to do what is right...always. The foundational conviction of this book is that leadership is a virtuous enterprise. It delivers authentic consequences through morally uplifting practices and credible actions fashioned in the crucible of strong character. The opportunity to make a difference in the lives of people is a rare privilege that is often birthed from adversity. Therefore, whenever you can, you must!

Being! invites you to fulfil your covenant of uplifting leadership in all of life's arenas, whether it be work, play, or love. Eschewing "dead feelings,

\footnotetext{
${ }^{3}$ Calcutt, A. (2016). The surprising origins of "post-truth" - and how it was spawned by the liberal left. Retrieved from http://theconversation.com/the-surprising-origins-of-posttruth-and-how-it-was-spawned-by-the-liberal-left-68929.

${ }^{4}$ Donald, B. (2016). Stanford researchers find students have trouble judging the credibility of information online. Retrieved from https://ed.stanford.edu/news/stanford-researchersfind-students-have-trouble-judging-credibility-information-online.
} 
dead ideas, and cold beliefs," it fans the flames of "hot and live" ones to crystallise leadership's futures' mindsets and zeitgeist virtues. ${ }^{5}$ Its content will be easier to understand, accept and assimilate into your existing repertoire if you are fully aware of the raconteurs' own underlying beliefs and their guiding canons. Prepare then, for a short preamble into the habits of the mind that can help you in your search for insightful meaning and rectitude.

\section{Beginner's Mind: Letting Go to Let In}

In a scene from the movie Doubt, Sister Aloysius (Meryl Streep) resists Father Flynn (Philip Seymour Hoffman) and his attempts to inject newness into the upcoming school Christmas pageant, with the fallacious deterrent that "there is nothing new under the sun." Before you hasten to judge her blunt obduracy however, pause to reflect that cynicism is the adornment of the expert - been there, done that, know how, will not refresh! The expert mind is a great ally in still waters. Knowing all the answers makes you look good and feel valuable to the organisation. Unfortunately, however, an expert mind is the mistress of yesterday's routines, and will cause tomorrow's challenges to engulf you, in a rapidly changing world. ${ }^{6}$ As Shunryu Suzuki, the zen master counsels, "If your mind is empty, it is always ready for anything; it is open to everything. In the beginner's mind, there are many possibilities; in the expert's mind, there are few."

\section{Mindfulness: Alert Attention is the Mother of Intelligence ${ }^{8}$}

The modern mind is held captive in the moment to many competing calls that require multitasking (see Figure 1). If anecdotal (and wishful?)

\footnotetext{
${ }^{5}$ James, W. (1902/2009). The varieties of religious experience: A study in human nature. New York, NY: Seven Treasures Publications.

${ }^{6}$ Dilworth, R. L. (1998). Action learning in a nutshell. Performance Improvement Quarterly, 11(1), 28-43.

${ }^{7}$ Suzuki, S. (1980). Zen mind, beginner's mind: Informal talks on zen meditation and practice. Boston, MA: Weatherhill (Shambala Publications).

${ }^{8}$ Kabat-Zinn, J. (1994). Wherever you go, there you are: Mindfulness meditation in everyday life. New York, NY: Hyperion. p. 10.
} 
4 Being! Five Ways of Leading Authentically in an iConnected World

self-reports are to be believed, your brain can do just that - react instantaneously to every stimulus it receives and still keep all the balls in the air!

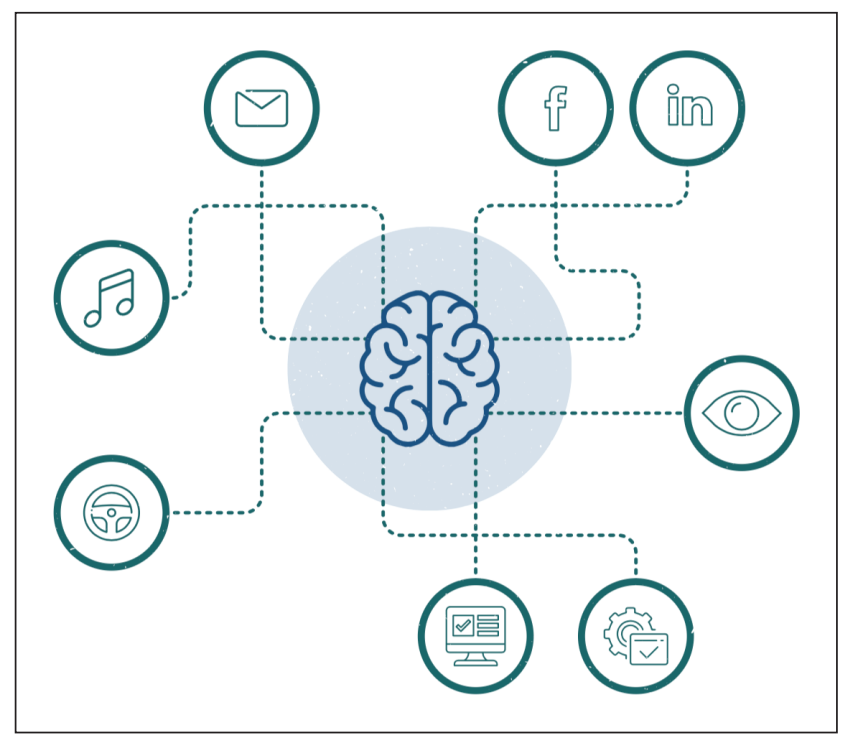

Figure 1. Competing calls on the modern mind

You pride yourself on your ability to cross a busy intersection unscathed, while simultaneously listening to a Spotify playlist, responding to an email, and reading a billboard. At your workplace, your attention floats apparently seamlessly between your Facebook feed, LinkedIn updates, email Inbox... and yes, your current work project that could be career-defining! You are convinced that multitasking is crucial because constant and ubiquitous social and professional connection gives you visibility and keeps you frontof-mind with your peers and your boss. ${ }^{9}$ More importantly, you believe with unwavering certitude that multitasking is something you are very good at because it comes naturally to you.

\footnotetext{
${ }^{9}$ Giang, V. (2016). These are the long-term effects of multitasking. Retrieved from https:// www.fastcompany.com/3057192/how-to-be-a-success-at-everything/these-are-the-longterm-effects-of-multitasking.
} 
Unfortunately, evidentiary reality bites! For a start, there are switching costs connected with multitasking. Every time you shift goals ("I want to do Task B now instead of Task A") and activate a different set of rules for the new task ("I'm turning off the rules for Task A, and turning on the rules for Task B"), you run the risk that your switching costs may conflict with your environment's demands for productivity and safety. ${ }^{10}$ Ergo, it is easy to listen to music when you are in the shower, but very fraught to glance at your email while driving on the freeway!

A second cost associated with a wandering attention has to do with specific situations. For example, many of you work in organisations that operate in volatile and unpredictable contexts. This regularly necessitates the need to abandon the "important," and redirect efforts to the "urgent and immediate." This crisis-driven reaction generates a trail of work-inprogress, that triggers an emotional and cognitive phenomenon called attention residue. Attention residue is your brain's inability to focus fully on a current activity because a prior activity still holds part of your attention. As you flit from one urgent task to another, the accumulating attention residue from previous tasks makes performance on subsequent tasks progressively worse. ${ }^{11}$

The putative bottom-line then, is that slowness and focus have merit for executive function. You are a peak performer only when you do "deep work" - extended periods of full concentration, on a single task, free from distraction. ${ }^{12}$ To quote the savant of mindfulness, Jon Kabat-Zinn: "Life is overwhelmingly interesting, revealing and awe-provoking when we show up for it wholeheartedly and pay attention to the particulars. ${ }^{13}$ Wherever you are...be there!"

\footnotetext{
${ }^{10}$ Rubinstein, J. S., Meyer, D. E., \& Evans, J. E. (2001). Executive control of cognitive processes in task switching. Journal of Experimental Psychology: Human Perception and Performance, 27(4), 763-797.

${ }^{11}$ Leroy, S. (2009). Why is it so hard to do my work? The challenge of attention residue when switching between work tasks. Organizational Behaviour and Human Decision Processes, 109(2), 168-181.

${ }^{12}$ Newport, C. (2016). Deep work: rules for focused success in a distracted world. New York, NY: Grand Central Publishing.

${ }^{13}$ Kabat-Zinn, J. (2005). Coming to our senses: Healing ourselves and the world through mindfulness. New York, NY: Hyperion.
} 


\section{Leadership is Purposeful: Finding the Rhythm and Choosing to Dance}

The ballads of our era urge us to introspect and take stock of our livedlives on a moment-to-moment chronometer. More than half a century ago, Bob Dylan was at the vanguard of this rhetorical soul-searching, with his timeless anthem, "How many times, can a man turn his head and pretend that he just doesn't see?"14 Apropos too was Diana Ross' breathless exhortation, "Do you know where you are going to?", as was Heather Small's more urgent call to action, "What have you done today to make you feel proud?"15 Serious answers to questions in this genre go to the heart of your reason for "being" - the meaning you make of your life and its purpose. As Victor Frankl, the Austrian neurologist and psychiatrist, quotes from Nietzsche: "He who has a 'why' to live for, can bear with almost any 'how.' Frankl should know - he was a Holocaust survivor. ${ }^{16}$

The responses to the "why" of life are myriad - limited only by the number of religious proselytisers, speculative philosophers and the doctrines they espouse. At one end of this metaphorical continuum stands Deep Thought, the computer in The Hitchhiker's Guide to the Galaxy, offering the number " 42 " as the answer to the "ultimate question of life, the universe, and everything." ${ }^{17}$ At the other end stand the organised religions of our epoch with their well-wrought scriptures, traditions, and deterministic beliefs. At both extremes, and everywhere in-between, blind faith is a pre-requisite to this kind of knowledge - "believing is seeing!"

Your search in this book focuses on less esoteric and more temporally situated queries. Therefore, rather than seeking the answer to the metaphysical question, "What is the purpose of life?", we will restrict our

\footnotetext{
${ }^{14}$ BobDylanTV (2012, September 11). Blowing In The Wind (Live On TV, March 1963). Retrieved from https://www.youtube.com/watch?v=vWwgrijIMXA

${ }^{15}$ Lynne, D. (2007, April 12). Diana Ross - Do you know (Diana Ross Live at Caesars Palace in Las Vegas September 1979) [video file]. Retrieved from https://www.youtube. com/watch?v=Uf4P6rGMxWs; Small, H. (2012, May 20). Heather Small — Proud [video file]. Retrieved from https://www.youtube.com/watch?v=OygsHbM1UCw

${ }^{16}$ Frankl, V. E. (2006). Man's search for meaning. Boston, MA: Beacon Press. (p. 76).

${ }^{17}$ Adams, D. (1997). The hitchhiker's guide to the galaxy. New York, NY: Ballantine Books. (pp. 160-161).
} 
inquiry to "What constitutes a purposeful life?" Aristotle answered this question two-thousand-three-hundred years ago in his Nicomachean Ethics. ${ }^{18}$ His theory is one you may find useful in shaping your own lives. Human good, he argued, was action that was habitually in accordance with universally venerated virtues such as wisdom, courage, humanity, justice, temperance and transcendence.

Happiness lies in the wilful choice and pursuit over time of morally praiseworthy activities. There is however, more to a purposeful and engaged life then the volitional selection of virtuous activity. As in the Olympic Games, so in life, you need to compete if you wish to be considered for the winner's crown. Only those who act can qualify to win the good things in life. Such action requires sense-making - tuning into the rhythm of your various universes - work, love, and play and being aware of everything that dances therein. ${ }^{19}$ When you are attentive to life's rhythms, opportunities will manifest themselves and you can choose whether you wish to "sit them out or dance." ${ }^{20}$ Aristotle's abiding counsel is that you must always choose to dance because excellence is a habit and you are what you repeatedly do!

\section{Art of the Possible: Whose Reality is it Anyway?}

Silvan Tomkins, the psychologist and personality theorist, underscored one of life's enduring dualities when he observed that, "some of us believe the world is to be discovered, while others believe it is to be invented." 1 At either end of Tomkin's observation lie the two opposite entities of the "Scientist" and the "Romantic" respectively (see Figure 2). ${ }^{22}$

\footnotetext{
${ }^{18}$ Aristotle, \& Ross, W. D. (2009). The Nicomachean ethics. Lexington, KY: World Library Classics. (pp. 13-14).

${ }^{19}$ Angelou, M. (2011, October 26). Everything in the universe has rhythm. Everything dances [Facebook status update]. Retrieved from https://www.facebook.com/MayaAngelou/ posts/10150373232074796.

${ }^{20}$ Womack, L.-A. (2009, October 8). Lee Ann Womack - I Hope You Dance [video file]. Retrieved from https://www.youtube.com/watch?v=RV-Z1YwaOiw

${ }^{21}$ Langer, E. J. (2009). Counterclockwise: mindful health and the power of possibility. New York, NY: Ballantine Books. p.45.

${ }^{22}$ Lakoff, G. (2003). Metaphors we live by. Chicago, IL: The University of Chicago Press. pp. 185-189.
} 
8 Being! Five Ways of Leading Authentically in an iConnected World

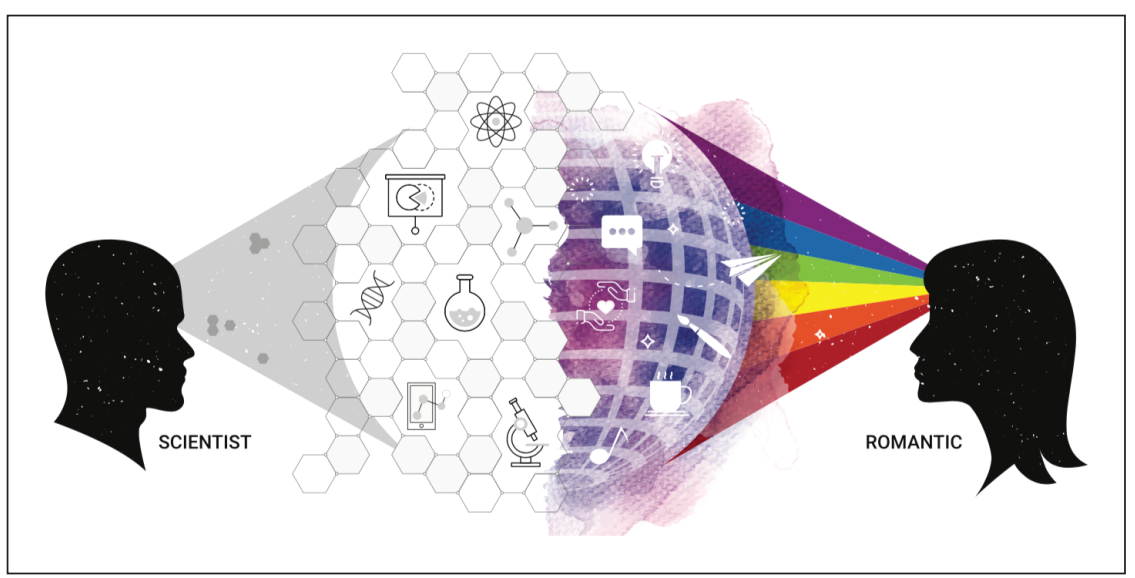

Figure 2. Objective and subjective views of the scientist and the romantic

The Scientist believes that the world is made up of objects that have inherent properties that are independent of your experience of them. These properties can be categorised and conceptualised accurately, provided you are objective. Objectivity, when seeking to understand things, implies a rational, impartial and unconditional point of view that avoids all human error. Human error is anything that impedes or distorts impartiality illusion, perception, judgment, emotions, prejudice and personal or cultural biases. The Scientist achieves "error-free" understanding by using the "scientific method" - a universally valid and unbiased process that allows her to rise above her subjective limitations. Objectivity and the scientific method used correctly and consistently, in endless repetitive cycles, helps her discover "reality" - the true nature of things." ${ }^{3}$

The Romantic, on the other hand, prizes subjectivity, emotions, intuitive insight, imagination, humanness, art and "higher" truth as the best guides to action when important issues arise. Feelings, aesthetic sensibilities, moral practices, and spiritual awareness are far better arbiters of personal truth and individual reality to the Romantic, than abstract, universal, impersonal, and rational objectivity. Objectivity from this viewpoint, is a mirage because personal, cultural, and contextual values

\footnotetext{
${ }^{23}$ Coughlan, P. \& Coghlan, D. (2011). Collaborative strategic improvement through network action learning: the path to sustainability. Cheltenham, UK: Edward Elgar.
} 
are inherent in every human project. ${ }^{24}$ Science is of no use to the Romantic when it comes to the most important things in life.

\section{Integrating Perspective: Social Construction of Meaningful Reality}

The Scientist and Romantic provide you with mutually exclusive choices. You can either believe in absolute truth or believe that you can make the world in your own image. This is a conundrum because your self-identity at various times is a balance between these two beliefs, rather than an absolute disregard of either one of them. You therefore need a unifying framework that pre-empts such dissipative conceptual face-offs. Social constructionism is such a world-view that brings together the ideas of an objective reality and a subjective interpretation of it, into a single perspective. ${ }^{25}$ The delineation of its conceptual cascade and an illustrative example, should aid understanding.

At its core, social constructionism posits that to create knowledge and meaningful reality, you must engage in the world to experience and interpret it. Importantly, what you take to be the world depends on how you approach it. Your approach in turn, depends on the social relationships of which you are a part, because the meaning you attribute to situations and events, originates in these relationships. ${ }^{26}$

Take for example, an event as primal as birth itself. Social constructionists do not dispute the objective reality of birth. They do however insist, that people will rely on traditions embedded in their web of social relationships to make sense of the occurrence.

Therefore, from a biological standpoint for example, birth is defined as the beginning of bodily functioning. From an Eastern theological view, birth marks a new cycle of life for the transmigrating soul. For the census clerk, it is fresh data for demography statistics. For close family, birth is the

\footnotetext{
${ }^{24}$ Lincoln, Y. S., \& Guba, E. G. (2013). The constructivist credo. Walnut Creek, CA: Left Coast Press.

${ }^{25}$ Ospina, S., \& Sorenson, G. L. J. (2006). A constructionist lens on leadership: charting new territory. In G. R. Goethals and G. L. J. Sorenson (Ed.), The quest for a general theory of leadership (pp. 188-204). Cheltenham, UK: Edward Elgar.

${ }^{26}$ Gergen, K. J. (2009). An invitation to social construction (2nd ed.). Thousand Oaks, CA: Sage Publications Limited. pp. 2, 26 \& 98.
} 
arrival of a new member who will propagate the family name into the next generation. For a stranger who does not know the child or the family in any way, the birth is a non-event. At the crux of this example is the notion that it is through relationships that we garner a tradition of sense-making that helps us construct the worlds we inhabit.

Social construction is a real and present reminder of the perspicacity of physicist Max Born's admonition that, "the belief that there is only one truth and that oneself is in possession of it...[is] the deepest root of all the evil in the world." ${ }^{27}$ When it comes to life's "realities," you would be well advised to heed the anthem of the post-hardcore Canadian band, Boys Night Out, to "hold on tightly, and let go lightly." 28

The social constructionist view has significant implications for your understanding of leadership. This is because it expands the traditional dimensions of leadership beyond the exercise of personal power and influence, to the nascent area of relational leading - contributing to the communal process that helps people move confidently into the future. ${ }^{29}$ Unlike the larger-than-life leadership of the "great man" genre, relational leadership is invisible because the stewardship of collective aspirations transpires in the space between people.

\section{Conclusion}

Six decades ago, George Miller, a cognitive psychologist from Princeton University wrote of the magical number seven (plus or minus two), as the number of objects an average human can hold in working memory. ${ }^{30}$ The authors believe that this introductory chapter, Leadership is Virtuous and Purposeful, would do well to heed his stricture and not overstay its welcome.

\footnotetext{
${ }^{27}$ Lipman-Blumen, J. (2005). The allure of toxic leaders: Why we follow destructive bosses and corrupt politicians - and how we can survive them. New York: Oxford University Press. p. 246.

${ }^{28}$ roxtarrr (Producer) (2009, October 24). Boys Night Out - Hold On Tightly, Let Go Lightly (LIVE) [video file]. Retrieved from https://www.youtube.com/watch? $\mathrm{v}=213 \mathrm{DvUB}-\mathrm{yMg}$ ${ }^{29}$ Drath, W., \& Palus, C. (1994). Making common sense: leadership as meaning making in a community of practice. Greensboro, NC: Centre for Creative Leadership.

${ }^{30}$ Miller, G. A. (1956). The magical number seven, plus or minus two: Some limits on our capacity for processing information. Psychological Review, 63(2), 81-97.
} 
Being! Five Ways of Leading Authentically in an iConnected World, began life more than six years ago. It was seeded as a year-long learning and development programme on leadership called, "Leading Self: Building Business Acumen and Rewarding Customer Relationships." This avatar of leadership learning was targeted at middle and senior managers, in two large regional and global banking and telecommunications businesses respectively. The programme then metamorphosed into a long-duration "Executive Leadership Programme," for functional leaders in schools, and system leaders in the Ministry of Education, across many states and territories in Australia and New Zealand. This book's antecedents are therefore rooted in leadership practice across many sectors and its raison d'etre is to build adaptiveness and resilience in uncertain times. It is endorsed by leaders who have honed their personal effectiveness, grown spiritually and become more effective and impactful, because of their engagement with the leadership learning that now forms this book's content.

We have channelled wisdom at the intersection of many disciplines and multiple world views to provide deeper insight and meaning to the leadership dilemmas and choices that you constantly face. Our waystations and foundational platforms include leadership and management theory, philosophy and contemplative practice, organisational behaviour, positive psychology and strengths-based perspectives, intercultural learning, experiential learning theory, action science and neuroscience.

Chapter 2, Survival and Growth in a Turbulent World foregrounds leaderships' adaptive challenges in uncertain times.

Chapter 3, Business and its Broken Paradigm introduces you to the concept of Paradigms and Paradigm-shifts and signals the advent of the iConnected paradigm, a world where radical relatedness and unbounded collaboration empower the individual.

Chapters 4, Breakthrough Insights at the Intersection, explains how the book learns from people, ideas, beliefs and philosophies to induct the three dimensions of leadership's futures mindset for an iConnected world. 
Chapter 5, Focussed Attention - First Dimension of Leadership's Futures Mindset argues that attending deliberately and wisely to experiences is crucial to success and happiness.

Chapter 6, Collaborative Spirit - Second Dimension of Leadership's Futures Mindset describes the emotional and cognitive basis of human ultrasociality and relates these concepts to friendships, trust and reciprocity in the virtual world.

Chapter 7, Collective Wisdom - Third Dimension of Leadership's Futures Mindset highlights the power of collective human consciousness for unlocking growth and transformation in individuals, organisations and communities in new and scalable ways.

The three core dimensions of leadership's futures mindset listed above, are a prequel to the Five Leadership Virtues of Being Present, Being Good, Being in Touch, Being Creative and Being Inclusive. The Practices associated with these Virtues, and the Enactments that bring these Practices to life are core to leading authentically in an iConnected world.

Chapters 8 and 9 explore the leadership virtue of Being Present, its associated practices of Developing Self and Excelling at Work and their enactments.

Chapters 10 and 11 explicate the leadership virtue of Being Good, its associated practices of Taking a Strengths-Based Perspective to Personal and Organisational Change and Using Positive Emotions to Lead an Authentic Life, and their enactments.

Chapters 12 and 13 elucidate the leadership virtue of Being in Touch, its associated practices of Engaging Diverse Intelligences when Responding to Life's Challenges and Understanding and Managing Self and Others, and their enactments.

Chapters 14 and 15 develop the leadership virtue of Being Creative, its associated practices of Recrafting Strategic Performance in Changing Times and Having a Prescient View, and their enactments.

Chapters 16 and 17 present the leadership virtue of Being Inclusive, its associated practices of World Citizenry and Culturally Contingent Leadership, and their enactments. 
The final Chapter 18, Listening to Practitioners' Voices and Learning from What They are Saying, collates insights from a research study undertaken with 167 practitioners from 16 industries in Australia and New Zealand to support the book's assertion that the 5 Ways of Being are central to leading authentically in an iConnected world.

We trust we have integrated both Western leadership-thinking with its more evidence-based, cognitive approaches, and Eastern philosophy with its more "mystical" and spiritually oriented homilies, into a rich tapestry that engages your attention, challenges your capabilities, and leaves you richer and more fulfilled for the effort.

Our intent and aspirations have made a lot of promises. We hope our combined enterprise in the pages that follow, keep them.

Welcome to Being!

Vikram and Aasha Murthy 